\title{
The Big Biosphere Experiment
}

\author{
J. T. Trevors • N. Stavros • M. H. Saier Jr.
}

Published online: 14 December 2007

(C) Springer Science + Business Media B.V. 2007

Our biosphere encompasses the shared existence of all living organisms, including the human and animal populations on Earth. As such, it is something that must be kept healthy to maintain stable relations between humans and Earth. That common ground we tread and the social fabric we form should not be used for a global experiment, especially when the driving forces are human greed, stupidity, and the allure of profits. Should a select group of people be allowed to make money while destroying the biosphere and abusing other people?

The human population presently increases by about 75 million annually, and our growing numbers have been assaulting renewable and non-renewable resources with selfish ferocity. That trend of consumption has been occurring for centuries, but as the

J. T. Trevors $(\bowtie)$

Department of Environmental Biology,

University of Guelph,

Guelph, Ontario, Canada NIG-2W1

e-mail: jtrevors@uoguelph.ca

N. Stavros $\cdot$ M. H. Saier Jr.

Division of Biological Sciences,

University of California, San Diego,

La Jolla, CA 92093-0116, USA

N. Stavros

e-mail:nstavv@gmail.com

M. H. Saier Jr.

e-mail: msaier@ucsd.edu human population skyrockets, the amassed hunger for resources is turning into an unstoppable craze-with profit as the primary goal. Child laborers are stripped of their rights. Several billion humans lack the basic resources to satisfy daily nutritional needs. Such people survive on a day-to-day basis, driven to scavenging, while affluent people drive inefficient vehicles to restaurants. A biosphere dominated by such greed resembles a careless, global experiment to see how far it can be taken. To what extent can people profit at the expense of contemporary suffering and the threat of widespread future suffering?

This experiment is founded on all the wrong values. There is little justification for excessive consumption for the privileged while the poor have no access to resources. These resources are not to be snatched away by the wealthy; they belong to the Earth and all its people - not just the power-hungry classes. Greed for wealth in a growing population leads to exhaustion of those resources and irrevocable damage to the biosphere. The preservation and improvement of our biosphere is beyond the realm of politics and national agendas. It is about survival and improvement of the human situation, and protection and survival of other species. It is about evolution towards global peace and stabilization of universal human rights. It is about a sustainable human population that does not consume every resource on the planet.

The big biosphere experiment has destroyed the fish stocks, laid bare the once vast reaches of forest, 
and disemboweled the Earth of its mineral innards. The result is a collection of wastelands gasping in the wake of massive consumption - of a select group of people willing to pollute and wreak havoc on our only atmosphere. Wars fought in the past century have ravaged infrastructure and brought suffering and death to huge numbers of people. The past century has seen the use of the atomic bomb in Japan, herbicide and napalm in Vietnam, and depleted uranium in a war in the Middle East allegedly waged against terror. These are only a few examples of tragic suffering that humans have brought upon their fellow beings and the Earth that houses them. They are assaults on both humanity and the biosphere, and clearly they are not the end product of rational thought. Yet we persist. Our wars are part of the feverish snatching of resources that work toward making things better for that select group, for those high-ranking figures in the corporate and political circle. This is not a rational approach to maintaining the biosphere.

Amid catastrophic political activities such as warfare, what is political about global climate change? The answer is nothing. Filtering data and information about climate change through a political system simply confirms that politicians and their advisors either fail to understand the science, or they do in fact understand, but are too busy playing politics to act appropriately. Their jobs consist of maintaining international relations, internal relations, and economic concerns. The subject of the biosphere is something they pretend they do not have to worry about, something they set outside of their own jurisdiction.

It is not acceptable for our human race to use the biosphere as a lab for an economic experiment motivated by greed and resulting in destruction. Why? The reason is simple. When the experiment reaches its end, and the critters involved are left to suffer with the shattered remains of their terrarium, we realize that we are all involved. Even though the wealthy can temporarily continue to seek profit without being directly affected, the eventual consequences of their greed will be resource depletion. Everything we share as living organisms will be gobbled up and hopelessly gone. The people of the Earth, rich or poor, will be left equally bereft of resources if the growing population continues to consume proportionally to their numbers. It is myopic stupor that has allowed humans to deplete many resources in the past. We need to look ahead. We cannot complete the experiment. The resulting pollution, climate change, famine, suffering, death, and crumbling infrastructure will leave humans struggling to survive as a shattered species.

We can predict the suffering caused by our own shortsightedness and actions. The corporate folks at the top of the experiment are causing too much contemporary misery through exploitation of workers, child labor, and reckless destruction of resources. The growing population only means a bigger market to them. Greed is the dominating factor of their decisions, encouraging them to lash out in whatever way possible to maximize profit. That must change. With the threat of collapse on the horizon, why not decrease human population growth, conserve our resources, and usher in an improved society? If the exponential growth subsides in favor of a sustainable, constant rate, then individuals would be better offwith universal rights and a supply of resources that will endure the needs of a stabilized population.

Greed and violence have no place in the biosphere. If every individual were to act for his or her own well being, the proper action would be nurturing the biosphere, not abusing resources for personal gain. One person's greed spurs the suffering of another, but everyone benefits if we can conserve resources to better sustain the human population. By reducing the rush for profit and slowing population growth, we act on behalf of humanity. All people are interconnected and linked to the biosphere. Cooperation for a common humanity is not a far-fetched goal. It is the better option of the two choices we have for our future. Intellectual and rational humans can come together to find the perfect range in which population growth does not run rampant and consume every last resource. The human population can back away from greed and quit the big biosphere experiment, or it can continue to grow unchecked, condemning the multitude of humans to suffer the consequences of its own ravenous consumption. 